Historic, Archive Document

Do not assume content reflects current scientific knowledge, policies, or practices. 



\section{A Few of The Ellis Originations}

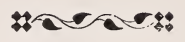

MONARCH OF TIIE GLFN The strongest growing glad in the (1927) garden-immense spike-large extreme(Mrs. M. G Ellis) ly ruffled or fluted, bright salmon pink florets This is in a class all by itself. (Only No. 1 b::lbs for sale this year)

Each $\$ 25.00$

STAR OF THE SEA (1926)

(Merton G. Ellis)
Peach red with rich brownish scarlet throat, tipped with lemon yellow points. No description can express the beauty of this glad. It linst be seen to be appreciated. $1 \mathrm{t}$ is well named, "Star of the Sea.".

Each $\$ 10.00$

\author{
RIPPI.ING WATERS \\ (1926) \\ (Mirton G. Ellis) \\ RED TORNADO \\ (1925) \\ (Merton G. Ellis)
}

PRIDE OF PORTLAND Cream, suffused with pink - large florets-very beautiful. ........................60

Strong growing, brilliant red witi: darker velvety throat. "It takes the world by storm, but ftorms dun't take it." Each $\$ 20.00$

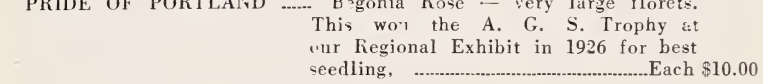

SIVORD OF MAHOMET .... An unusual shade of purplish, bro: ${ }^{\prime \prime}$ (1926) ish red-a strong grower-tall straight (Mיrton G. Ellis) spike with well placed florets. An interesting oddity. ..................................... $\$ 2.00$

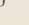


CYNTHIA

(1927)

(Mrs. M. G. Ellis)
A pink glad, about the color of a wild rose beautifully shaded with deeper pinh-a yellow throat giving her the effert of having been "moon struck." A tall straight spike, quite large, well arranged florets siightly ruffled, many open at a time-a good keeper as a cut flower. Each $\$ 3.00$
LADY MACBETH (1927)

(Mrs. M. G. Ellis)
Large, scarlet florets with two large white blotches in throat having a thin dark red line rumning through the center of each. Many florets open at nnce-good spike-very striking, Each $\$ 3.00$
BENGAL BEAUTY (1927)

(Mrs. M. G. Eilis)
This is a cross between Bengal Tiger and Golden Measure. The spike is tall and strong like Golden Measure. but has more the color of Bengal Tiger, only more brilliant markings and more gold in it. The color does not fade before the florets wilt. It attracts much attention,

Each $\$ 3.00$
OREGON QUEEN

(1927)

(Mrs. M. G. Ellis)
Clear cream with yellow throat. Tall grareful spike - large wide open florets, seven or more open at a time. This glad resembles a spike of lovely lilies, Fach $\$ 5.00$

\section{One half size bulbs of all the above except MON- ARCH OF THE GLEN and OREGON QUEEN may be had for $1 / 2$ price of No. 1 bulb, and 10 bulb?ets for price of one No. 1 bulb.}

\section{SET I} $\$ 10.00$

8 Pulblets Each of: Star Of The Sea Rippling Yaters Pride of Portland Red Tornalo

Sword of Mahomet

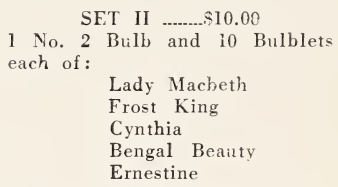

5 bulblets of:

Oregon Queen
SET III

Special Frost King Set:

1 No. 3 )

3 No. 5 )

4 No 6 )
$\$ 2.50$

Bulbs and 15 Bulblets

of Frost King. 


\section{SPECIAL OFFER}

SET IV

$\$ 15.00$

Heavenly Blue

2 Bulblets

Veiled Brilliance

3 Bulblets

Longfellow

Mr. Frederick Christ

10 Bulblets

Joerg's White

2 Bulblets

1 No. 4 Buib and

5 Bulblets.

SET $V$

$\$ 7.50$

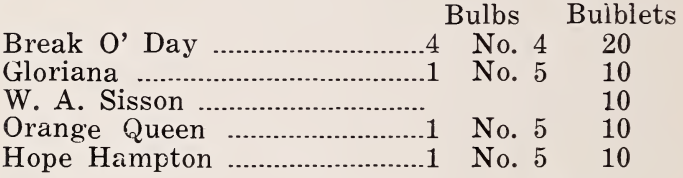

SET VI

$\$ 5.00$

Bulbs Bulb!ets

Aristocrat

No. 510

Gladdie Boy .............................1 No. 5 10

Serrata ……............................. No. 5 N 10

Betty Joy …………………..... No. 5

SET VII

$\$ 5.00$

Bulbs Bulblets

Los Angeles

No. 3

25

Priority

No. $4: 25$

Giant Nymph

No. $5 \quad 25$

Marshall Foch

No. 5

25

Fastidious

No. 3

25

Frost King

2 No. 3

10

You may substitute equal value of Break O' Day, Gloriana', or Joerg's White for any item you wish omitted in any set.

Extras with every order.

No order for less than $\$ 5.00$ worth, except the $\$ 2.50$ Special Set of Frost King.

All orders are received subject to prior sale, and are shipped either postpaid or express prepaid.

Please send remittance with order to:

THE MERTON G. ELLIS BULB GARDENS

Canby, Oregon 